\title{
ПІДХОДИ ДО НАВЧАННЯ КУРСАНТІВ ЮРИДИЧНИХ СПЕЦАЛЬНОСТЕЙ ПЕРЕКЛАДУ
}

\begin{abstract}
Метою статті є обтрунтування методології навчання англійської мови фахівиів, які є курсантами Академї Державної пенітенціарної служби, на першому (бакалаврському) рівні вищої освіти з галузі знань спеціальності «Правоохоронна діяльність» та «Право». У статті розглядається специфіка навчання майбутніх юристів перекладу, визначаються методичні підходи до навчання фахівців юридичних спеціальностей перекладу. У статті висвітлено теоретичні положення, які передбачають аналіз наукових джерел щуодо навчання перекладу різної категорії учнів (курсантів, студентів, учнів середньої школи тощо), ретроспективно розглянуто методи та підходи до організачії навчання двомовного перекладу в дисертаційних дослідженнях. У статті запропоновано такі підходи, як культурологічний, міждисииплінарний та особистісно-діяльнісний щзодо навчання майбутніх юристів перекладу на заняттях з англійської мови. Визначено, що під час навчання юристів перекладу слід ураховувати культурні відмінності рідної та англійської мов з огляду на поведінку, оцінювання та комунікативні ситуації, в яких беруть участь фахівці юридичних спеціальностей. Виокремлено принции міждисциплінарності в навчанні перекладу, щзо показує взаємозв'язок $і$ взаємовплив навчальних дисциплін майбутніх юристів у вищому освітньому закладі, які викладалися або викладаються під час навчання студентів/курсантів англійської мови професійного спрямування, оскільки переклад стосується різноманітних галузей юридичних знань. Реалізація особистісно-діяльнісного підходу до навчання перекладу передбачає максимальне врахування індивідуально-психологічних, вікових, національних особливостей та інтересів курсантів/студентів (когнітивних, психологічних та фізіологічних); створення системи вправ та завдань, щцо враховують індивідуальні особливості кожного курсанта/студента та максимально розкривають їхні можливості.
\end{abstract}

Ключові слова: методологічні підходи, майбутні юристи, переклад, англійська мова.

Oksana BYKONIA, orcid.org/0000-0002-8865-8792

Doctor of Pedagogical Sciences, Associate Professor, Professor at the Department of the Foreign Languages Academy of the State Penitentiary Service (Chernihiv, Ukraine) oksanabikonya@ukr.net

\section{APPROACHES OF TEACHING TRANSLATION TO FUTURE LAWYERS}

The aim of this article is to substantiate the methodology of teaching English to specialists at the first (bachelor's) level of higher education in the field of "Law Enforcement" and "Law", who are cadets and students of the Academy of the State Penitentiary Service. It is defined the specifics of teaching translation to future lawyers. In this work the methodical approaches of teaching translation to the specialists in legal specialities are determined. The article highlights the theoretical statements that involve analysis of existing methods and approaches of organization of teaching translation in various establishments. It is pointed out the analysis of scientific sources for teaching translation to different categories of pupils (cadets, students, schoolchildren, etc.) it is considered retrospectively different methods and approaches of organization of teaching bilingual translation in various kinds of research. In this article the author defines and describes such methodological approaches as cultural, interdisciplinary and personally-oriented activity of teaching translation to future lawyers at English classes. It is determined that while teaching translation to future lawyers, the cultural differences of English and native languages should be taken into account according to the behaviour, assessment and communicative situations in which legal specialists take part in. The principle of interdisciplinary of teaching translation is highlighted. It is said that it combines the relationship and interaction of disciplines of future lawyers in higher education, which have been taught before or are being taught now while students and cadets are studying English as a discipline. It is stressed that translation of legal oral and written texts in English or Ukrainian relates to various parts of legal knowledge. This knowledge includes types of law such as basic legal terms and concepts, legal resources and sources of law, different types of documents, court etiquette in the USA, the Great Britain, Ukraine and other countries in the world. Due to the implementation of a multidisciplinary approach of teaching translation to the specialists in legal specialities the 
students and cadets can produce some adequate translation of legal texts and transmit the main idea/part of this law information. It is defined that implementation of the personally-oriented activity approach of teaching translation involves such components as individual and psychological, age and national peculiarities, and interests of cadets and students (cognitive, psychological and physiological); making up a system of exercises and tasks according to each cadet/student to maximize his or her capabilities, individual characteristics, etc.

Key words: methodological approaches, future lawyers, translation, English.

Постановка проблеми. На сучасному етапі під час формування у курсантів і студентів юридичних спеціальностей англійської комунікативної компетентності робиться акцент на оволодінні ними англійською мовою як засобом міжкультурної комунікації, як інструментом у діалозі рідної та іноземної культур. Майбутні фахівці юридичної галузі мають володіти англійською мовою не лише на побутовому рівні, але беруть участь у міжнародних конференціях, семінарах, круглих столах, освітніх програмах для обміну досвідом щодо міжнародних досягнень для їхньої подальшої професійної діяльності, різноманітних судових слуханнях тощо. Майбутні юристи повинні бути плідними учасниками міжкультурної комунікації та спроможними у сферах професійного та ситуативного спілкування в різних видах мовленнєвої діяльності, що включають тематику юриспруденції.

Ми погоджуємося 3 О. Б. Тарнопольским та С. П. Кожушко, що в закладах вищої освіти навчання іноземної мови повинно мати професійно спрямований характер та враховувати потреби спеціалізації курсантів та студентів (Тарнопольский, Кожушко, 2004). У нас це відноситься до навчання англійської мови фахівців, які є курсантами Академії Державної пенітенціарної служби, на першому (бакалаврському) рівні вищої освіти з галузі знань спеціальності «Правоохоронна діяльність» та «Право».

Навчальна дисципліна «Іноземна (англійська) мова» займає особливе місце в підготовці фахівців для кримінально-виконавчої служби України, зумовлена професійними потребами цієї категоpiї учнів, спрямована на опанування англомовної комунікативної компетентності професійного спрямування, сприяє оволодінню новітньою фаховою інформацією з іноземних джерел тощо.

Отже, все більшого розвитку й удосконалення потребує методика навчання майбутніх юристів англійського професійного спрямування, особливо навчання перекладу юридичних текстів.

Аналіз досліджень. Ретроспективний аналіз досліджень щодо теорії та практики перекладу, організації навчання іншомовного перекладу тощо показує, що цим проблемам присвячені роботи як закордонних, так і українських науковців, таких як I. Р. Абдулмянова, I. С. Алексеєва, Л. С. Бархударов, С. В. Бреус, В. Г. Гак, Н. В. Зіну- кова, Т. А. Казакова, Т. Р. Кияк, В. Н. Комісаров, I. В. Корунець, Л. К. Латишев, Р. К. МіньярБелоручев, Н. В. Новосельцева, Т. Д. Пасічник, О. Л. Пумпянський, В. В. Стрілець, Г. В. Чернов, A. П. Чужакин, R. Bell, B. Haris, А. A. Hurtado, C. Nord, B. Sherwood, G. Shreve, R. Stolze та ін.

Вчені описали сутність перекладу, визначили трактування різних видів перекладу, способи його здійснення та місце перекладу в навчально-виховному процесі. Зокрема, В. Н. Комісаров визначив прийоми роботи з текстом, виокремив моделі перекладу, перекладацькі трансформації, стратегії перекладу, лексичні, граматичні, стилістичні й прагматичні аспекти перекладу; запропонував критерії оцінювання якості виконаного перекладу тощо та детально описав вправи для навчання перекладу. Т. В. Ганічева розробила методику навчання майбутніх філологів усного двостороннього перекладу в галузі прав людини. В. І. Карабан описав проблеми навчання перекладу англійської наукової і технічної літератури. Н. В. Кондрашова описала методику навчання перекладу студентів образотворчих факультетів педагогічних вищих закладів освіти. С. А. Королькова спроєктувала текстологічну модель навчання перекладу наукової і технічної літератури. С. А. Королькова запропонувала текстологічну модель навчання перекладу. Л. О. Ніколаєва визначила проблеми навчання іноземних учнів професійно орієнтованого перекладу. В. В. Сафонова теоретично розробила та експериментально перевірила методику формування усної перекладацької компетентності у сфері професійного спілкування. С. В. Трофімова дослідила проблему навчання суспільно-політичного перекладу. Л. М. Черноватий розробив методику викладання перекладу як спеціальності та запропонував підхід до розроблення загальної моделі системи вправ і завдань для навчання перекладу. Т. Д. Пасічник описала методику навчання майбутніх філологів письмового перекладу комерційних листів. Я. Г. Фабрична систематизувала зміст компетентності майбутніх філологів у письмовому перекладі методичних текстів. В. Д. Ігнатенко розробила методику навчання майбутніх філологів анотативного й реферативного науково-технічного перекладу з французької мови. А. О. Христолюбова обгрунтувала та розробила методику навчання студентів перекладацьких 
факультетів письмового перекладу текстів економічної тематики з французької мови. I. Р. Абдулмянова вивчала особливості формування двомовного тезауруса перекладача 3 французької мови в економічній сфері, виділила термінологію й особливості граматичної організації наукового економічного тексту. Т. П. Василенко аналізувала особливості навчання майбутніх філологів перекладу публіцистичних текстів. В.В.Стрілець розглядала питання щодо визначення компетентності в письмовому перекладі майбутніх технічних перекладачів, предметний аспект змісту навчання майбутніх бакалаврів філології письмового науково-технічного перекладу тощо.

Щодо проблеми перекладу юридичних текстів у навчально-виховному процесі, то такі вчені, як Н. М. Антонюк, С. В. Власенко, Т. В. Ганічева, Д. І. Демченко, О. В. Дробаха, Н. В. Зінукова, В. І. Карабан, Т. Є. Малєєва, С. М. Нікіфорова, І. Орлова, Л. М. Черноватий та інші досліджували ці питання. Так, Н. М. Антонюк та О. В. Дробаха досліджували правничу термінологію в змісті викладання іноземних мов та переклад юридичних термінів у сфері інтелектуальної власності з англійської українською мовою тощо. С. В. Власенко детально проаналізував договірне право та обгрунтував особливості професійного перекладу в мовній парі англійська та російські мови. С. М. Нікіфорова досліджувала безеквівалентний переклад юридичної лексики в англійській і українській мовах. У роботі А. Г. Ніколенко проаналізовано лексико-семантичний аспект багатокомпонентних термінів та їх переклад. І. Орлова запропонувала принципи перекладу текстів міждержавних угод.

Також особливо важливим моментом для нашого дослідження $є$ створення для студентів юридичних спеціальностей навчальних та навчально-методичних посібників, наприклад, таких: В. I. Карабан «Переклад англійської наукової і технічної літератури. Граматичні труднощі, лексичні, термінологічні та жанрово-стилістичні проблеми» (Карабан, 2004), Л. М. Черноватий, В. І. Карабан «Переклад англомовної юридичної літератури» (Черноватий, Карабан, 2006), Т. Є. Малєєва, Л. М. Черноватий, Т. В. Ганічева, Н. В. Зінукова, Д. І. Демченко «Переклад міжнародних англомовних угод українською мовою: Три базові угоди у галузі прав людини» та Книга для викладача до цього навчального посібника для студентів вищих закладів освіти (Малєєва та ін., 2017) тощо.

Незважаючи на велику кількість досліджень щодо навчання перекладу, методика навчання перекладу курсантів/студентів юридичних спеціальностей Академії Державної пенітенціарної служби України потребує дослідження та створення в галузі психолого-педагогічних наук.

Треба зазначити, що аналіз наукових та навчально-методичних джерел показує, що існують різноманітні методи й підходи до розв'язання проблеми навчання перекладу на заняттях з іноземних мов, але проблема навчання курсантів та студентів юридичних спеціальностей двомовного перекладу, передусім в Академії Державної пенітенціарної служби України, ще не досить досліджена. Отже, в контексті нашого дослідження необхідно з'ясувати провідні підходи щодо навчання курсантів та студентів перекладу.

Метою статті $\epsilon$ визначення основних методичних підходів до навчання курсантів юридичних спеціальностей двомовного перекладу на заняттях 3 англійської мови.

Виклад основного матеріалу. Зауважимо, що для курсантів та студентів юридичних спеціальностей переклад не може бути метою навчання, оскільки висококваліфікованих перекладачів готують спеціальні заклади вищої освіти. Результатом повинно бути безперекладне розуміння юридичної літератури іноземною мовою. Безперекладне розуміння тексту трактуємо як розуміння тексту під час читання, аудіювання, усного та писемного продукування його рідною мовою. Переклад може виступати як засіб навчання усного та писемного мовлення, читання, аудіювання та розуміння текстів юридичного характеру та як засіб контролю рівня володіння англомовною комунікативною компетентністю, наприклад, під час навчання читання та розуміння тексту юридичного характеру.

Для досягнення мети навчання англійської мови професійного спрямування викладач має навчити студентів та курсантів отримувати загальну інформацію про якесь явище в джерелі юридичного напряму та швидко й точно добирати необхідну інформацію 3 прочитаного/прослуханого джерела. Слідом за Н. А. Бараненковою вважаємо, що матеріалом для навчання перекладу має бути текст $з$ юриспруденції, який має низку характерних рис, таких як складність інформації та ії викладення в усному та письмовому тексті через вживання професійної термінології, специфічних граматичних засобів (наприклад, синтаксично заплутаних конструкцій), що сприяють стислості та послідовності оповіді тощо, та, на нашу думку, стандартизованість, логічність, відсутність образності, оскільки ці тексти належать до офіційноділового стилю (Бараненкова, 2013: 78).

Згідно 3 дослідженням А. О. Подорожної, навчання курсантів та студентів юридичних спеціальностей англійської мови припускає не лише 
повне та точне розуміння мови, вміння правильно продукувати свою думку, використовуючи юридичну термінологію, але й опанування навичок юридичного перекладу для обміну інформацією між фахівцями юридичної галузі (Подорожна, 2018: 61). Курсанти і студенти мають опанувати декларативні та процедурні знання, передусім знання спеціальної термінології як мовою оригіналу, так і мовою перекладу, знання в галузі юриспруденції, до якої належить усний та письмовий текст, що перекладається, знання української мови для грамотного викладу інформації.

На основі аналізу наукових праць та нашого дослідження вважаємо за доцільне здійснювати навчання майбутніх юристів перекладу на засадах культурологічного, міждисциплінарного та особистісно-діяльнісного підходів (Bykonia, Borysenko, Gruba, Mosenkis, Chystiak, 2020).

Розглянемо ці підходи в контексті нашого дослідження.

В основі культурологічного підходу лежить поняття культури. Згідно 3 дослідженням H. J. Vermeer культура трактується як складна система, що передбачає людські дії або поведінку, включаючи мову та мовлення, де ілюструється кожне явище в комплексній системі цінностей, а кожна особистість $є$ елементом системи просторово-часових координат (Vermeer, 1987). Культура - це динамічне явище, що показує поведінку та дії людини в певній галузі, в нашому випадку юриспруденції. Культура професійного спілкування включає етикет (певний кодекс правил поведінки різної категорії юристів, їхню професійну мову та мовлення) ведення досудового слухання, судового процесу, поведінку судді, присяжних, прокурора, адвоката тощо в різних ситуаціях професійного спілкування.

Погоджуємося з О. А. Кальниченко, що переклад є передачею тексту однією мовою засобами іншої мови, перенесенням явищ однієї культури в іншу, оскільки процес перекладу відбувається в контексті культури та є частиною культурного діалогу та розвитку цільової культури (Кальниченко, 2017). А отже, згідно з дослідженням цього вченого, навчання майбутніх фахівців юридичних спеціальностей перекладу слід розглядати під ракурсом того, що переклад текстів є результатом навчальновиховної діяльності, а тексти, які в самій цільовій культурі вважаються за переклади, слід порівнювати $з$ текстами цієї самої культури, щоб зрозуміти суть культурного явища тощо (Кальниченко, 2017).

У контексті нашої статті, на основі дослідження I. С. Бахова (Бахов, 2011), опанування майбутніми юристами міжкультурної компетентності в перекладі під час їхньої професійної діяльності $€$ інтегративним особистісним утворенням 3 комплексом знань, умінь, ціннісних орієнтацій для здійснення успішності міжкультурної діяльності з вирішення професійних завдань в умовах міжкультурної взаємодії в стилі співробітництва й толерантності, а згідно 3 І. Ю. Голуб (Голуб, 2010) - тримання дистанції від рідної культури, здійснення контролю власної культурної детермінованості, чутливості до можливих культурних відмінностей, усвідомлення проблемних моментів у міжкультурній комунікації, передбачення міжкультурних непорозумінь з метою успішного подолання лінгвоетнічних бар'єрів та забезпечення комунікативно-функціональної еквівалентності оригіналу і перекладу.

Під час навчання юристів перекладу слід ураховувати культурні відмінності рідної та англійської мов 3 огляду на поведінку, оцінювання та комунікативні ситуації, в яких беруть участь фахівці юридичних спеціальностей.

Отже, під час створення вправ та завдань для навчання перекладу необхідно розробляти вправи та завдання для інтегрованого формування компетентності в перекладі та лінгвосоціокультурної компетентності в усному та писемному спілкуванні, включає вправи для розвитку навичок та вмінь для здійснення успішності міжкультурної діяльності з вирішення професійних завдань в юриспруденції.

Навчальна дисципліна «Іноземна (англійська) мова» пов'язана 3 такими дисциплінами, як «Українська мова професійного спрямування», «Історія держави та права закордонних країн», «Конституційне право України», «Кримінальне право», «Кримінальний процес», «Кримінологія», «Кримінально-виконавче право» тощо. Саме завдяки міждисичилінарному підходу в майбутніх юристів формується база фонових знань 3 таких тем, що містять: структуру судів (районних, апеляційних, державних та Верховного судів), судів присяжних, судової тяжби та апеляції; використання юридичних джерел, офіційного/неофіційного листування та написання документів; особливості судової системи Великої Британії, США, України тощо; різні типи злочинів, кримінальної відповідальності за злочини різного характеру, види покарань; в'язниці та їхні види; пробацію; засудження тощо.

Принции міждисциплінарності в навчанні перекладу передбачає взаємозв'язок та взаємовплив навчальних дисциплін майбутніх юристів у закладі вищої освіти, тобто в Академії Державної пенітенціарної служби, які викладалися або викладаються під час навчання студентів/курсан- 
тів англійської мови професійного спрямування, оскільки переклад включає знання галузі «Право» та «Правоохоронна діяльність».

Ми цілком поділяємо думку Н. М. Антонюк та О. В. Дробахи, що юридичний переклад, наприклад, документів, пов'язаний з певними труднощами (Антонюк, Дробаха, 2013: 125-126). Так, неможливо перекласти договір, не розуміючи тонкощів англійської юридичної термінології та характерної фахової термінології тощо (Антонюк, Дробаха, 2013).

Реалізація міждисииплінарного підходу до навчанняперекладупередбачаєте,щостуденти/курсанти будуть спроможні здійснювати адекватний переклад юридичних текстів та передавати основну суть інформації, тонкощі юриспруденції тощо.

3 позиції особистісно-діяльнісного підходу центральним у навчанні перекладу є курсант/студент, тобто суб'єкт навчальної діяльності. Під час навчання курсантів/студентів необхідно передбачати максимальне врахування: 1) когнітивних, психологічних та фізіологічних особливостей, особливо індивідуально-психологічних, вікових, національних, та інтересів курсантів/студентів; 2) створення системи вправ та завдань, що враховують індивідуальні особливості кожного курсанта/студента, щоб максимально розкрити можливості кожного курсанта/студента.

Слідом за С. Коломієць та С. Кулєзньовою під час навчання майбутніх юристів перекладу маємо враховувати вплив психологічних процесів та станів, а саме увагу, темперамент, пам'ять, мислення на мовленнєвий продукт, тобто текст усного чи письмового перекладу (Коломієць, Кулєзньова, 2016: 215-216). Під час навчання перекладу формуються відповідні навчальні стилі та здійснюється розвиток необхідних особистісних якостей. Вчені зазначають, що навчання усного та письмового текстів слід розглядати з різних боків: $у$ nuсb- мовому перекладі слід зосередити увагу на проблемі розуміння тексту оригіналу, оскільки його неповне нерозуміння впливає на якість перекладу, а в усному перекладі вагомим є розвиток концентрації уваги, оперативної пам'яті та здатності мінімально реагувати на частотні та загальновідомі фрази 3 текстів (Коломієць, Кулєзньова, 2016).

Таким чином, згідно 3 дослідженням особистісно-діяльнісного підходу до навчання курсантів юридичних спеціальностей перекладу центральним у цьому навчально-виховному процесі є курсант/студент як суб'єкт навчальної діяльності, а тому створення методики організації майбутніх юристів 3 формування компетентності в перекладі має здійснюватися 3 урахуванням індивідуальних особливостей курсантів/студентів; рівня сформованості компетентності в перекладі; 3 наданням курсанту/студенту навчальних матеріалів і навчальних завдань різних рівнів складності залежно від його навчальних досягнень, здібностей, інтересів та можливостей, способів рефлексії, самоконтролю та самооцінювання своєї діяльності; особистого досвіду та темпу роботи в процесі перекладу іншомовного усного та писемного тексту юридичної направленості, застосуванням індивідуальних, парних, групових форм роботи під час інтерпретації іншомовного юридичного тексту; 3 добором змісту навчання перекладу з урахуванням потреб щодо їхньої майбутньої професійної діяльності.

Висновки. Таким чином, у результаті дослідження ми дослідили, що організацію навчання майбутніх юристів перекладу слід здійснювати на основі таких методологічних підходів, як культурологічний, міждисциплінарний та особистіснодіяльнісний.

Наступний напрям нашого дослідження дослідити вимоги щодо рівня володіння майбутнім юристом компетентності в перекладі.

\section{СПИСОК ВИКОРИСТАНИХ ДЖЕРЕЛ}

1. Антонюк Н. М., Дробаха О. В. Переклад юридичних термінів у сфері інтелектуальної власності з англійської українською мовою. Вісник Академї адвокатури України. 2013. Вип. 2 (27). С. 124-128.

2. Бараненкова Н. А. Роль перекладу в процесі навчання читанню фахової літератури студентів немовних ВНЗ. Вісник ЛНУ імені Тараса Шевченка. 2013. № 14 (273). Ч. II. С. 77-81.

3. Бахов I. С. Формування професійної міжкультурної компетентності майбутніх перекладачів у вищому навчальному закладі : автореф. дис. ... канд. пед. наук: 13.00.04 ; Нац. акад. внутр. справ. Київ, 2011. 20 с.

4. Голуб І. Ю. Формування у майбутніх перекладачів соціокультурної компетенції у процесі вивчення німецької мови після англійської : дис. ... канд. пед. наук: 13.00.02 ; Київ. нац. лінгв. ун-т. Київ, 2010. 368 с.

5. Коломієць С., Кулєзньова С. Сучасні підходи до навчання перекладу як міжкультурної взаємодії. Науковий вісник Східноєвропейського національного університету імені Лесі Украӥнки. 2016. Вип. 6. С. 212-216.

6. Подорожна А. О. Організація процесу навчання науково-технічному перекладу студентів інженерно-педагогічних спеціальностей. Virtus. 2018. Вип. 29. С. 60-62.

7. Тарнопольский О. Б., Кожушко С. П. Методика обучения английскому языку для делового общения. Київ : Ленвит, 2004. 192 с.

8. Кальниченко О. А. Теорія перекладу. Харків : Вид-во НУА, 2017. Ч. 1. 64 с. 
9. Main Approaches of Business English Teaching to Future Lawyers: A Case Study of Ukrainian Higher Institutions. International Journal of Learning, Teaching and Educational Research / O. Bykonia et al. 2020. Vol. 19/ № 6. P. 46-61.

10. Vermeer H. J. What does it mean to translate? Indian Journal of Aplied Linguistics. 1987. Vol. 13 (2). P. $25-33$.

\section{REFERENCES}

1. Antoniuk N. M., Drobakha O. V. Pereklad yurydychnykh terminiv u sferi intelektualnoi vlasnosti z anhliiskoi ukrainskoiu movoiu. [The legal translation in the sphere of intellectual property from English into Ukrainian]. Bulletin of the Academy of Advocacy of Ukraine, 2013, Nr. 2(27), pp.124-128. [in Ukrainian]

2. Baranenkova N. A. Rol perekladu u protsesi navchannia chytanniu fakhovoi literatury studentiv nemovnykh VNZ. [The Role of Translation in Teaching Reading of Professional Literature of Students of Non-language High Institutions]. Bulletin of Luhansk Taras Shevchenko National University, 2013, Nr. 14 (273). Part. II, pp. 77-81. [in Ukrainian]

3. Bakhov I. S. Formuvannia profesiinoi mizhkulturnoi kompetentnosti maibutnikh perekladachiv u vyshchomu navchalnomu zakladi. [Formation of professional intercultural competence of prospective interpreters in a higher educational institution]: avtoref. dys. ... kand. ped. nauk. 13.00.04. National Academy of Internal Affairs. Kyiv, 2011, 20 p. [in Ukrainian]

4. Holub I. Yu. Formuvannia u maibutnikh perekladachiv sotsiokulturnoi kompetentsii u protsesi vyvchennia nimetskoi movy pislia anhliiskoi. [Development of Socio-Cultural Competence in Translation Students in Course of Learning German after English]: dys. ... kand. ped. nauk: 13.00.02. Kyiv National Linguistic University. Kyiv, 2010. 368 p. [in Ukrainian]

5. Kolomiets S., Kulieznova S. Suchasni pidkhody do navchannia perekladu yak mizhkulturnoi vzaiemodii. [Modern Approaches to Teaching Translation as Cross-Cultural Interrelation]. Scientific Bulletin of the Lesia Ukrainka East European National University, 2016, Nr. 6, pp. 212-216. [in Ukrainian]

6. Podorozhna A. O. Orhanizatsiia protsesu navchannia naukovo-tekhnichnomu perekladu studentiv inzhenerno-pedahohichnykh spetsialnostei. [Organization of the scientific and technical translation teaching process to students of engineer-pedagogical specialities]. Virtus, 2018, Nr. 29, pp. 60-62. [in Ukrainian]

7. Tarnopolskiy O. B., Kozhushko S. P. Metodika obucheniya angliyskomu yazyiku dlya delovogo obscheniya. [Methodology of teaching Business English communication]. Kyiv : Lenvit, 2004. 192 p. [in Russian]

8. Kalnychenko O. A. Teoriia perekladu. [Translation theory]. Kharkiv : NUA, 2017. Part 1. 64 p. [in Ukrainian]

9. Bykonia O., Borysenko I.V., Gruba T.L., Mosenkis Iu.L., Chystiak D.O. Main Approaches of Business English Teaching to Future Lawyers: A Case Study of Ukrainian Higher Institutions. International Journal of Learning, Teaching and Educational Research, 2020, Vol. 19, No. 6, pp. 46-61.

10. Vermeer H. J. What does it mean to translate? Indian Journal of Aplied Linguistics, 1987, Vol. 13(2), pp. $25-33$. 